Papers and Proceedings of the Royal Society of Tasmania, Volume 108

(ms. received 30.11 .1973 )

\title{
A NEW MIDDLE CAMBRIAN POLYMERID TRILOBITE FROM NORTH-WESTERN TASMANIA
}

by J.B. Jago

Department of Applied Geology South Australian Institute of Technology

(with two text figures and one plate)

\section{ABSTRACT}

A new species of trilobite, Pianaspis(?) Zeveni, is described from the Radfords Creek Group, Dial Range Trough, north-western Tasmania. Its age is late Middle Cambrian, either of the Lejopyge Zaevigata II Zone, or the L. Zaevigata III Zone.

INTRODUCTION

The purpose of this paper is to describe a new species of polymerid trilobite, Picnaspis(?) Zeveni from the Radfords Creek Group of the Dial Range Trough, northwestern Tasmania. The position of the fossil locality containing Pianaspis(?) Zeveni is shown in fig. 1. The sediments containing Pianaspis(?) Zeveni are those referred to by Banks (1956, p. 184) as "Argillite, with Lejopyge etc." Banks (1962) notes the presence of Lejopyge Zaevigata from the same locality. Burns (1964, p. 47) tabulated a succession from the same locality which he termed the Sugarloaf Gorge. Pianaspis(?) Zeveni comes from Unit 13 in the succession tabulated by Burns (op. cit.). Jago (1973, Table 2) recorded the following trilobites from Unit 13: ?Lejopyge Zaevigata (Dalman), Lejopyge Zaevigata armata (Linnarsson), Pseudophalacroma (?) sp., Ptychagnostus (Goniagnostus) sp., Hypagnostus ef. brevifrons (Angelin), Diplagnostus sp., a species of new genus cf. Clavagnostus sp., and Pianaspis (?) sp. This faunal list indicates that the age of the fauna is late Middle Cambrian, either of the Lejopyge Zaevigata II Zone or the $L$. Zaevigata III Zone. Fossil groups apart from the trilobites are unknown from Unit 13.

Pianaspis (?) Zeveni is the species noted in Jago (1973) as Pianaspis (?) sp. It is significant in that it is the only polymerid trilobite known at present from Unit 13 despite intensive collecting. Further it is known only from one stratigraphic level. The palaeoecological significance of these and other factors in relation to the fauna of Unit 13 are discussed in Jago (1973).

The morphological nomenclature used below is that used in Moore (1959). The catalogue numbers refer to the collection of the Geology Department, University of Tasmania.

\section{SYSTEMATIC DESCRIPTION}

Superfamily PTYCHOPARIACEA Matthew, 1887

Family PAPYRIASPIDIDAE Whitehouse, 1939

Genus PIANASPIS Saito and Sakakura, 1936

Synonymy: See Chernysheva, 1970, p. 123.

Type species: Pianaspis Kodairai Saito and Sakakura, 1936, p. 114, p1. 8, figs. 1-3.

Diagnosis: See Chernysheva, 1970, p. 124 .

Discussion: Chernysheva (1970) reviewed Pianaspis. She placed Tosotychia Öpik in synonymy with Prohedinia Lermontova and Chernysheva and Prohedinia in synonymy with Pianaspis. Öpik (pers. comm.) agrees that Tosotychia is a junior synonym of Prohedinia. 


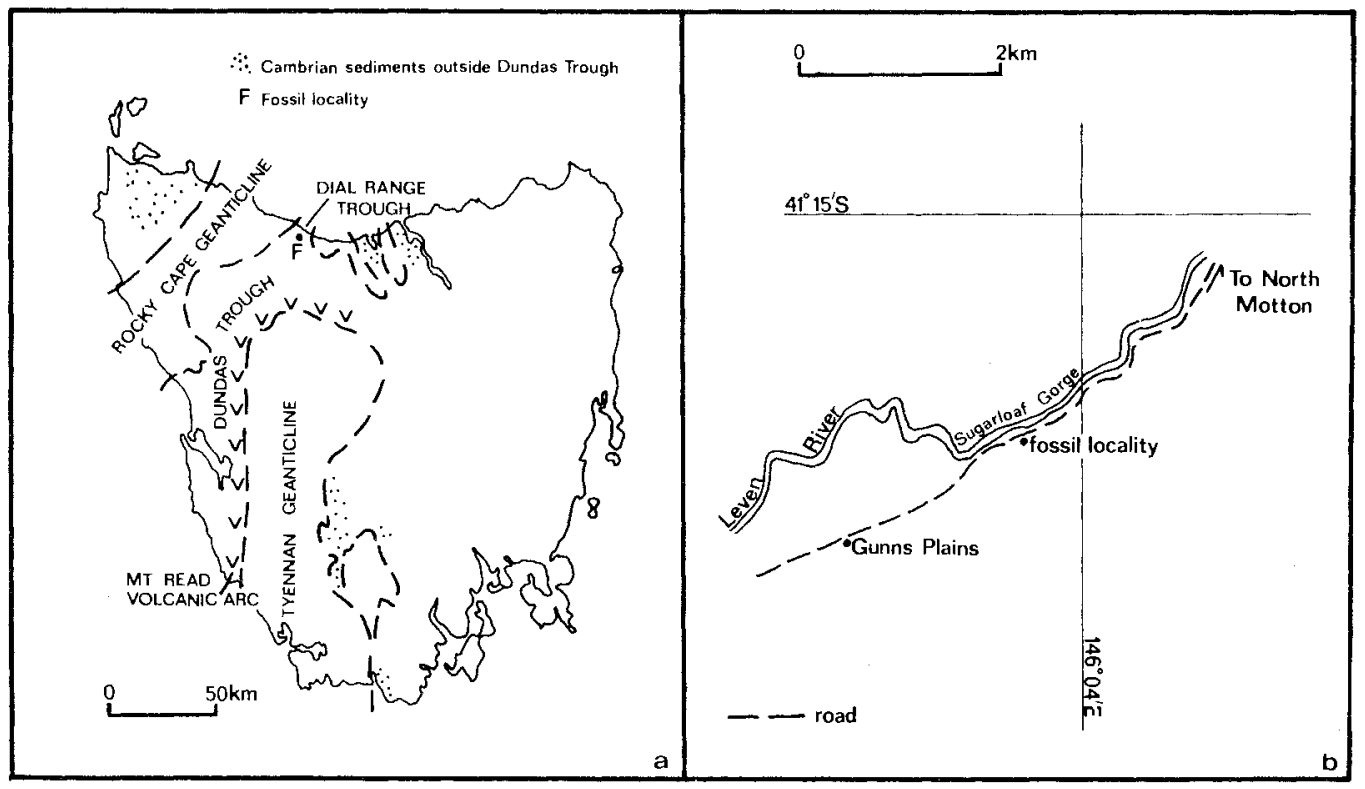

FIG. 1. - (a) Tasmanian Cambrian palaeotectonic framework (after Corbett at al., 1972). (b) Fossil locality in Sugarloaf Gorge on main road to Gunns Plains.

Chernysheva had at her disposal numerous examples of Prohedinia attenuata, the type species of Prohedinia, but had no specimens of Pianaspis kodairai. The photographs of Pianaspis kodairai shown in Saito and Sakakura (1936, pl. 8, fig. 1-3) are not particularly clear. It seems to me that Chernysheva should have obtained actual specimens of P. kodairai before placing Prohedinia (and thus Tosotychia) in synonymy with Pianaspis. Until such time as a detailed comparison of actual specimens of Prohedinia atenuata and Pianaspis kodairai is made, the synonymy of Prohedinia and Pianaspis is herein accepted with some reservations.

Öpik (1961, p. 148ff.) discussed the Papyriaspididae at length, especially the genera Papyriaspis, Tosotychia (=Pianaspis) and Chancia. He distinguished the Papyriaspididae from the Ptychopariidae on the single criterion that the former family has more than 16 thoracic segments. The form described below has an incomplete thorax (only eight segments preserved) and thus cannot be placed in either the Papyriaspididae or the Ptychopariidae on this basis. Opik (op. cit.) placed the Papyriaspididae in the Ptychopariacea rather than in the Dikelocephalacea as was done in Moore (1959). Öpik's classification is followed here.

The cranidium is reasonably well preserved, and a combination of the characteristics of the cranidium and the thorax indicate that this form is related to Pianaspis sors (Öpik). Recorded differences are not considered great enough to distinguish it on a generic level from Pianaspis sors. However, the number of thoracic segments in the new species, Zeveni, is unknown, and thus it is only tentatively assigned to the genus Pianaspis. 
Pianaspis (?) Zeveni sp. nov.

(p1. 1, figs. 1-12, text fig. 2)

Material: One almost complete cranidium, two partial cranidia (one of which is known as the internal mould), part of eight thoracic segments and one partial free cheek are reasonab1y well preserved. There are three hypostoma and a specimen with a partial cranidium and the two anterior thoracic segments. These are poorly preserved. There are also some isolated cranidial and thoracic segments. All specimens come from the one horizon, and because there are no other polymerids known from this section, all specimens are placed in the one species.

Measurements: Holotype cranidium (UT 92671), lengths, total 10mm; axial 1obe, 7.1mm; preglabellar area, $2.9 \mathrm{~mm}$; widths, glabella (anterior), 3.8mm; glabella (posterior), $4.2 \mathrm{~mm}$; across palpebral lobes, $13.5 \mathrm{~mm}$. Thoracic segments (UT 92671), total length of the eight thoracic segments, 10.6mm. Hypostome (UT 92674) (pl. 1, fig. 8), exposed length, $3.2 \mathrm{~mm}$.

Selection of Holotype: The cranidium (UT 92671) (p1. 1, figs. 1-5) is chosen as the holotype.

Diagnosis: Pianaspis(?) Zeveni sp. nov. has a slightly tapered glabella, abaxially curved anterior facial sutures, gently curved posterior facial sutures, and prominent, narrow, elevated eye ridges. The anterior glabellar border is slightly to strongly elevated above the preglabellar field. There is a wide (tr.), narrow (sag.) plectrum. On the palpebral area of each fixed cheek, immediately adjacent to the palpebral lobe, is a low dome-like structure. The wide, deep almost straight posterior border furrow widens and deepens abaxially; the axial glabellar furrows are deep. Genal caeca are seen clearly only on the preglabellar field and on the frontal areas of the fixigenae. There is no occipital spine; there are no thoracic axial spines; the pleural spines are of moderate length.
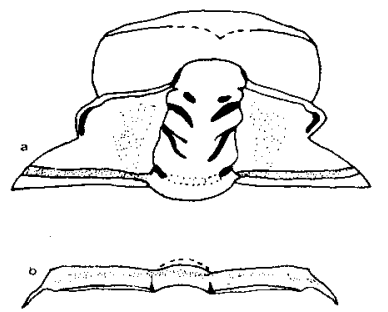

\section{Description}

Cranidium: The cranidium is about twice as wide as is long. The axial lobe has a length about two-thirds that of the cranidium; it is quite convex and stands out well above the rest of the cranidium, which is either gently convex or gently concave. The fixed cheeks are wide; the palpebra1 areas of the fixed cheeks have about the same width as the glabella.

From the posterior end of the palpebral lobes the posterior branches of the facial sutures diverge greatly. Close to the posterior end of each posterior branch, the facial suture has a very slightly convex (in an abaxial

FIG. 2. - Pianaspis(?) Zeveni direction) outline. The centroanterior part of the postsp. nov. (a) cranidium based on Plate 1 , figs. 1,7 and 12 . (b) thoracic segment (based on Plate 1 , fig. 10). The slight distortion seen in the specimens from Sugarloaf Gorge is retained in the above figures. erior branches are almost straight; in the posterior part of the posterior branches they are curved strongly backwards.

The anterior sections of the facial suture are gently curved. From the anterior ends of the palpebral lobes the sutures diverge slightly up to a point about one-third of the distance to the marginal furrow; from this point they converge gently to the marginal furrow. On the anterior border the facial sutures converge strongly; each branch of the facial suture cuts the frontal margin a little over half-way to the median line from the points where they cut the marginal furrow. 
The palpebral lobes, situated opposite the centre of the axial lobe, are poorly preserved in all specimens and have a length about 0.35 that of the glabella. They are gently convex and slope at a high angle into the wide, shallow palpebral furrows. The palpebral furrows are a continuation of narrow furrows which occur immediately to the posterior of the eye ridges throughout the entire length.

The narrow, elevated eye ridges are quite prominent. They appear to be single except in the adaxial region of the left hand eye ridge of UT 92671 (pl. 1, fig. 2) where there appear to be signs of a furrow between two separate ridges. They are directed slightly backwards from the glabella. The eye ridges are straight except at either end; the adaxial ends are curved forward and in the axial furrow the extreme ends of the ridges are almost parallel to the glabella; they meet the axial furrows just to the anterior of the most anterior glabellar furrows. The abaxial end of each ridge has a sharp backward bend in it before merging with the palpebral lobe. In this bend the elevation of the ridge is markedly increased.

The preglabellar field has a length about 0.2 that of the cranidium. The anterior border is slightly elevated in some specimens, but strongly elevated in others above the preglabellar field; it is separated from both the preglabellar field and the anterior area of the fixed cheeks by a shallow marginal furrow. The anterior border in its central region is slightly lower than it is abaxially. Across the preglabellar field the marginal furrow is deflected backwards to form a wide (tr.) but narrow (sag.) plectrum. The anterior areas of the fixed cheeks are gently convex and are highest posterolaterally. They slope gently down to the preglabellar field and the marginal furrow.

Immediately to the adaxial of the palpebral lobes, the palpebral areas of the fixed cheeks are strongly convex and form low dome-like structures. On the fixed cheeks (adjacent to the glabella) extending from near the $2 \mathrm{p}$ glabellar furrows to the posterior margin of the cranidium are low raised areas which widen backward and rise to a low maximum toward the posterior. Apart from these features the palpebral areas of the fixed cheeks are almost flat or slightly concave; these concave areas extend posteriorly across the posterior areas of the fixigenae to the posterior marginal furrows, becoming narrower and shallower to the posterior. The rest of each fixed cheek between this depressed area, the posterior branch of the facial suture and the posterior border furrow is almost flat except at the extremities where it slopes away.

The posterior border furrows are almost straight, wide and deep, becoming wider and deeper abaxially. The posterior borders are narrow becoming wider abaxially. On the fixed cheek there are small granules scattered over the surface.

The occipital ring is short (sag.), elevated and gently convex. The occipital furrow is wide and moderately deep being slightly deeper at the lateral extremities, which are directed strongly to the anterior. Overall the glabella tapers slightly forward; at its flatly rounded anterior end it has a width about 0.9 that at the posterior.

The glabella is outlined by narrow axial furrows which deepen to the anterior. The furrows are deepest where the eye ridges meet them. To the anterior of this point the furrows shallow markedly and only extend a little way around the front of the glabella.

There are four pairs of glabellar furrows. The most posterior pair (1p) meet the axial furrows about half way from the occipital furrow to the points where the eye ridges meet the axial furrows. They are deep, bifurcating and directed inward and very strong$1 y$ backwards. The more posterior branches of the bifurcating pairs are much the deeper of the two; the posterior branches almost meet across the top of the posterior end of the glabella. 
The second pair of glabellar furrows (2p) are directed inwards and backwards, but not as markedly as in $1 p$. They arise from about half way between where the eye ridges meet the axial furrows and the point where the $1 \mathrm{p}$ furrows meet the axial furrows. The $2 \mathrm{p}$ furrows are wide and deep but not as deep as the $1 \mathrm{p}$ furrows.

The third pair of lateral glabellar furrows ( $3 p$ ) occur as medium sized shallow depressions which do not reach the axial furrows. The fourth pair of lateral glabellar furrows ( $4 \mathrm{p}$ ) occur as small indentations in the glabellar margin immediately to the posterior of where the eye ridges meet the axial furrows. The $3 p$ and $4 p$ furrows have a similar arrangement to that figured for the two anterior glabellar furrows of Pianaspis sors (0̈pik) in öpik, 1961 (fig. 50). Between the points where the eye ridges meet the axial furrows and where the $2 p$ furrows meet these furrows the glabella appears to be slightly but distinctly expanded. This is especially evident in specimen UT 92671 (p1. 1, fig. 1). This feature does not appear to be present in UT 92673 (pl. 1, fig. 7). However, as UT 92671 is the better preserved specimen, it is considered that this feature is present in the species.

Genal caeca are seen clearly on the cranidium only on the preglabellar field and the frontal area of the fixigenae. The caeca have a reticulate pattern and are more prominent in front of the eye ridges than in front of the glabella where they are weak. In UT 92671 there is a very faint reticulation visible on the right hand palpebral area immediately to the posterior of the eye ridge. This cannot be seen in the photographs.

Free Cheek: Only one partially preserved free cheek is available. It is gently convex. The marginal region is poorly preserved, but there is a shallow, narrow marginal furrow and a border which is only slightly elevated above the furrow. There is a long genal spine as a continuation of the border. Genal caeca which radiate from the eye region are faintly visible.

Hypostome: No complete hypostome is available; most of the following description is based on the best preserved hypostome (p1. 1, fig. 8).

The strongly convex hypostome, when complete, is probably as wide (across the anterior wings) as is long. Most of the hypostome consists of the strongly convex median body. The border furrow is narrow and of moderate depth, except across the anterior and where it is shallow. The border is of moderate width. The anterior border is flat; the rest of the border appears to be convex and slightly elevated. The anterior wings are large, flat and triangular. Maculae are absent.

Thorax: The total number of thoracic segments is unknown. The most complete specimen of a thorax has only eight segments. The following description is based on these segments.

The axial region of each segment has a width about one-fifth that of the segment (including spines). The articulating device is not seen in any specimen. The axis is strongly convex. Across the anterior end of each segment there is a shallow concave furrow which narrows and deepens abaxially with small pits close to the axial furrows. The posterior part of the axis is slightly elevated and quite convex. Separating the axis from the pleurae are narrow axial furrows which have shallow axial sockets at the posterior and shallow anteriorly.

Each pleural segment is almost flat with a moderately deep pleural furrow which is directed abaxially and posteriorly. The furrow is close to the anterior margin adaxially, but in the abaxial third it tends to be close to the centre of the segment. It widens slightly abaxially, up to the base of the spine; the pleural furrows extend slightly into the base of the spine. Each spine is directed strongly to the posterior and is of moderate length. There is a gentle slope from the main part of the pleural segment down to the spine. The posterior flange is very narrow. There are no signs of pleural caecae.

\section{Pygidium: This is unknown.}


Discussion: Pianaspis sors (Öpik) is the best illustrated and described species of Pianaspis. For this reason Pianaspis(?) Zeveni is compared in detail with P. sors.

Pianaspis(?) Zeveni sp. nov. differs from $P$. sors in that it has no thoracic axial spines, and the pleural spines of leveni are decidedly longer than in sors. The genal spines in leveni are longer than those of sors. There is no occipital spine in leveni as there is in sors. The axial glabellar furrows of leveni are deeper than those of sors. In marked contrast to the situation in sors, there is very little sign of genal caeca to the posterior of the eye lines on Zeveni although this could be due to the preservation of leveni. The $1 \mathrm{p}$ and $2 \mathrm{p}$ furrows of leveni are directed more sharply to the posterior than in sors. The eye ridges in the latter are double whereas in leveni they appear to be single except in the case of UT 92671 mentioned in the description. $P$. sors has a posterior and an anterior parafrontal band; $P .(:)$ leveni has neither of these features.

The anterior branches of the facial sutures of Zeveni diverge slightly to the anterior of the palpebral lobe and then converge in a smooth curve to the anterior marginal furrow. Those of sors are sub-parallel according to öpik (1961, p. 162 and fig. 50). However, an inspection of the photographs of P. sors (Opik, op. cit. pl. 15, figs. 1, $2,3)$ indicate that they are somewhat convergent.

The glabella of Pianaspis(?) Zeveni is not as tapered as that of either $P$. attenuata or $P$. sors but is similar to $P$. kodairai in this respect. The lp glabellar furrows of $P$. (?) Zeveni are directed more sharply to the posterior than are those of either $P$. attenuata or $P$. kodairai. The anterior cranidial border of $P$. (?) leveni narrows markedly in an abaxial direction as does that of $P$. sors; in both $P$. attenuata and $P$. kodairai there is little change in width along the anterior cranidial border. $P$. sibirica Solovjev differs from other species of Pianaspis in having a very narrow preglabeliar field.

The writer agrees with Chernysheva (1970) that Prohedinia brevifrons Palmer (1968, p. 69, pl. 4, fig. 9) does not belong in Pianaspis. Chancia palliseri (Walcott) included by Palmer (1968, p. 69) in Prohedinia does not belong in Pianaspis; it has only two pairs of glabellar furrows (Rasetti 1951, p. 214) as compared with the four in Pianaspis. The cranidium, doubtfully assigned to Chancia odarayensis by Rasetti (1951, pl. 33, fig. 15) and included by Palmer (op. cit.) in Prohedinia, seems close to Pianaspis. This specimen, which has four pairs of glabellar furrows, appears to have a caecal pattern in front of the eye ridges (Rasetti, 1951, pl. 33, fig. 15) although Rasetti does not mention this in his description.

Occurrence and Age: Pionaspis(?) Leveni sp. nov. comes from Unit 13 of the lower sedimentary sequence of the Radfords Creek Group as exposed along the road to Gunns Plains; its age is either of the Lejopyge laevigata II Zone or the L. Zaevigata III Zone.

\section{ACKNOWLEDGEMENTS}

Most of this work was done during the tenure of a Commonwealth Post Graduate Award at the University of Adelaide. The later stages of this work were supported by a grant from the Australian Research Grants Committee. Dr. B. Daily (Geology Department, University of Adelaide) offered valuable advice and criticism.

\section{REFERENCES}

Banks, M.R., 1956: The Middle and Upper Cambrian Series (Dundas Group and its Correlates) in Tasmania. El Sistema Combrico, Proc. 20th Int. geol. Congr., 2, pp. 165-212.

Banks, M.R., 1962: Cambrian System in The Geology of Tasmania. J. Geol. Soc. Aust., 9, pp. 127-146. 


\section{J.B. Jago}

Burns, K.L., 1964: Geology of the Devonport Sheet, 1-mile Geol. Map Series K55-6-29. Explon. Rep. Geol. Surv. Tasm.

Chernysheva, N.E., 1970: Revision of Middle Cambrian trilobites of the genus Pianaspis. Paleont. Zh. (for 1970), 2, pp. 122-124. In Russian.

Corbett, K.D., Banks, M.R., and Jago, J.B., 1972: Plate Tectonics and the Lower Palaeozoic of Tasmania. Nature Physical Science, 240, pp. 9-11.

Jago, J.B., 1973: Cambrian agnostid communities in Tasmania. Lethaia, 6, pp. $405-421$.

Moore, R.C. (Ed.), 1959: Treatise on Invertebrate Paleontology, Part 0, Arthropoda 1. Univ. Kansas Press and Geol. Soc. Am.

Opik, A.A., 1961: Cambrian geology and palaeontology of the headwaters of the Burke River, Queensland. Bulz. Bur. Miner. Resour. Geol. Geophys. Aust., 53.

Palmer, A.R., 1968: Cambrian trilobites of East-Central Alaska. Prof. Pap. U.S. geol. Surv., 559-B.

Rasetti, F., 1951: Middle Cambrian stratigraphy and faunas of the Canadian Rocky Mountains. Smithson. misc. Collns., 116, no. 5 .

Saito, K., and Sakakura, K., 1936: Description de deux nouvelles especes de Trilobite. J. geol. Soc. Japan, 43, pp. 112-117. 
PLATE 1

Pianaspis(?) Zeveni sp. nov.

Figs. 1-5 UT 92671, holotype cranidium; fig. 1, dorsal view, x3.3; fig. 2, 1eft anterolateral part of glabella showing eye ridge meeting glabellar furrow, $x 9$; fig. 3 , right posterolateral part of cranidium, $x 5.5$; $f i g$. 4 , left posterolateral part of cranidium, $x 5.5$; fig. 5 , right anterolateral part of glabella showing eye ridge meeting glabellar furrow, $x 9$.

Fig. 6 UT 92672, right librigena, $\times 4$.

Fig. 7 UT 92673, partial cranidium, $\times 7$.

Figs. 8, 9 UT 92674; fig. 8, hypostome, x9.4; fig. 9, hypostome, x11.3.

Fig. 10 UT 92671 , part of eight thoracic segments, $\times 3.8$.

Fig. 11 UT 92675, poorly preserved cranidiun plus anterior pair of thoracic segments, xl1.5.

Fig. 12 UT 92676, internal mould of partial cranidium $x 5$.

Except for the specimen in Fig. 12, all photographs are of rubber casts made from external moulds.

A11 specimens come from Unit 13, lower sedimentary sequence Radfords Creek Group, as exposed on the main road to Gunns Plains, lat $41^{\circ} 16.1^{\prime} \mathrm{S}$, long, $146^{\circ} 03.7^{\prime} \mathrm{E}$. 
J.E. Jago
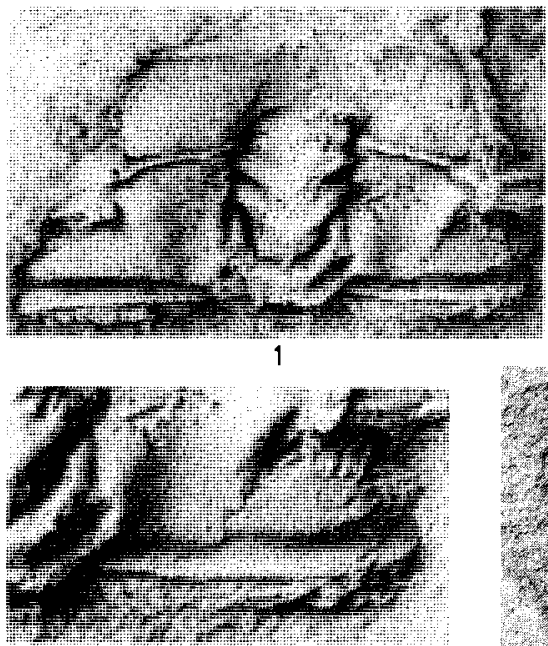

3

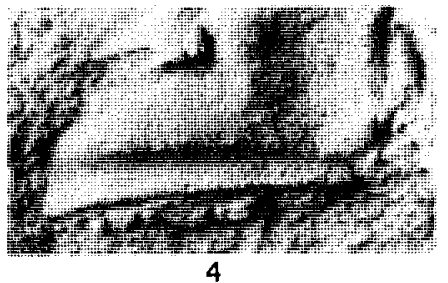

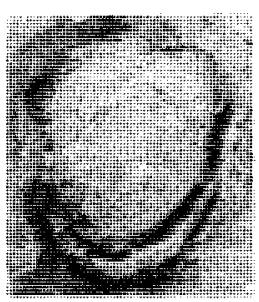

8

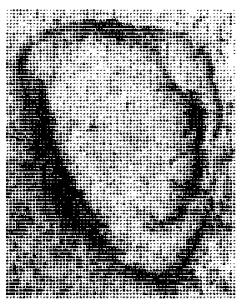

9

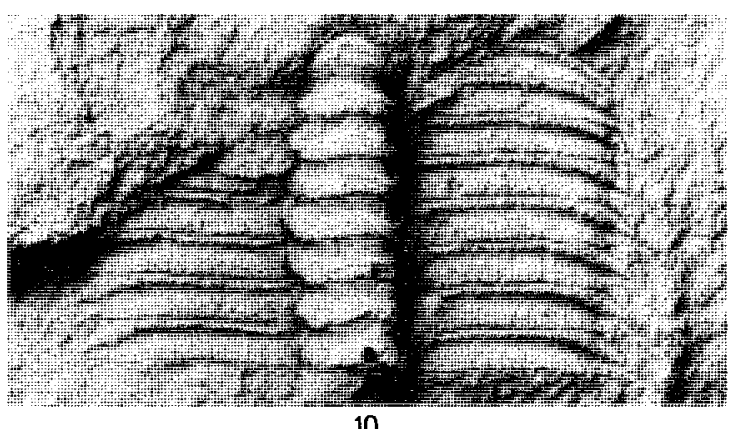

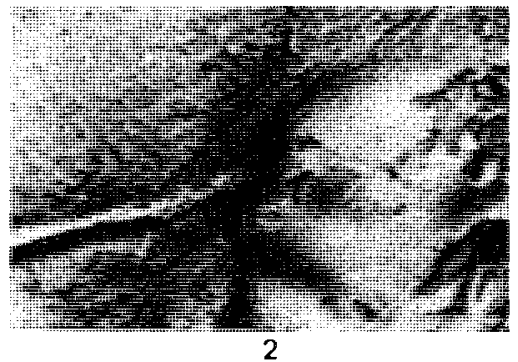

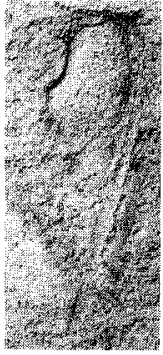

6

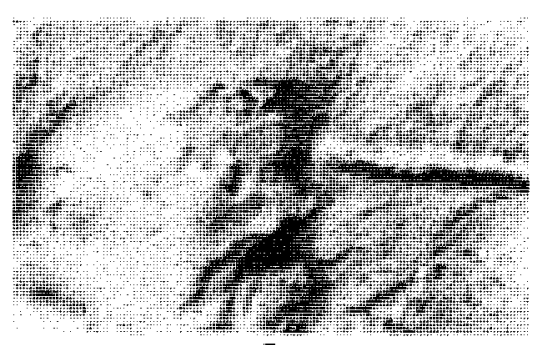

5
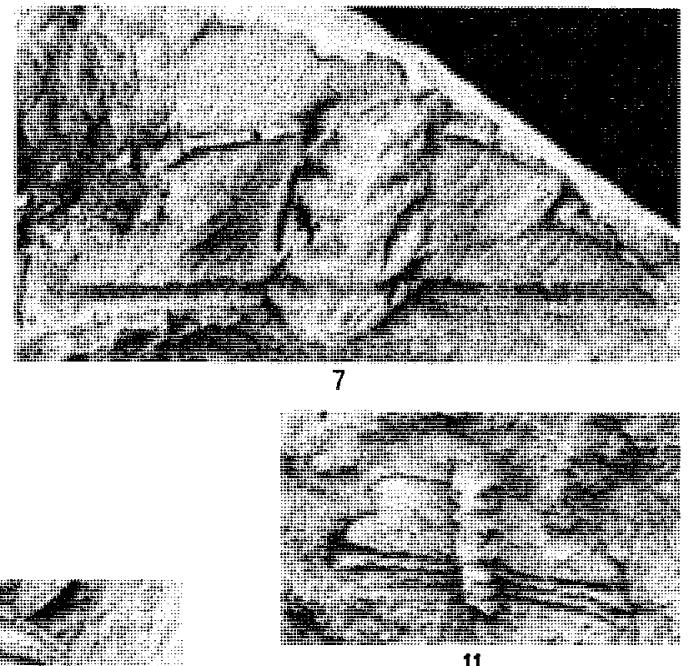

11

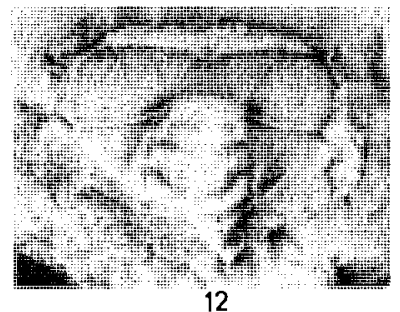

